\title{
Metropolisation and health in Orléans : when the metropolitan institution allows new territorial actions
}

Métropolisation et santé à Orléans : quand l'institution métropolitaine ouvre de nouveaux champs d'action

Pierre Allorant, Sylvain Dournel and Fouad Eddazi

\section{OpenEdition}

\section{Journals}

Electronic version

URL: https://journals.openedition.org/rfst/1547

DOI: $10.4000 /$ rfst. 1547

ISSN: 2492-3672

This article is a translation of:

Métropolisation et santé à Orléans : quand l'institution métropolitaine ouvre de nouveaux champs d'action - URL : https://journals.openedition.org/rfst/1502 [fr]

Publisher

Espaces et SOciétés (UMR 6590)

Electronic reference

Pierre Allorant, Sylvain Dournel and Fouad Eddazi, "Metropolisation and health in Orléans : when the metropolitan institution allows new territorial actions", Revue francophone sur la santé et les territoires [Online], Decentralization and territorialization of health, Online since 19 January 2022, connection on 14 February 2022. URL: http://journals.openedition.org/rfst/1547 ; DOI: https://doi.org/10.4000/rfst. 1547

This text was automatically generated on 14 February 2022

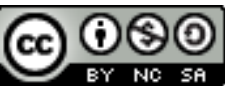

La Revue francophone sur la santé et les territoires est mise à disposition selon les termes de la Licence Creative Commons Attribution - Pas d'Utilisation Commerciale - Partage dans les Mêmes Conditions 4.0 International. 


\title{
Metropolisation and health in Orléans : when the metropolitan institution allows new territorial actions
}

\author{
Métropolisation et santé à Orléans : quand l'institution métropolitaine ouvre de \\ nouveaux champs d'action
}

Pierre Allorant, Sylvain Dournel and Fouad Eddazi

1 Can a metropolitan institution influence and improve the care supply for its inhabitants? This question guides the analysis of Orléans Métropole's new health action. The health context explains the will of the inter-municipal structure to manage this issue: the number of medical doctors is not sufficient to cover the population needs.

2 Faced with this deficiency, the mayors come into play, for example by creating multidisciplinary health centres (Figure 1). But the scale of the care offer makes these strictly municipal responses insufficient. Metropolitan intervention then seems legitimate to coordinate, arbitrate, and regulate the local public action. For this purpose, in the absence of a legal competence on the treatment offer, deliberation of November 15, 2018 has given to Orléans Métropole an optional competence to coordinate set-up and maintenance projects for health professionals.

3 However, this metropolitan policy is incomplete, due to the lack of explicit legal foundations to establish its legitimacy and benefit from effective tools. Legally, the skills that can be leveraged are limited. Indeed, the Metropolis has no strategic skill concerning the health care offer: it cannot define the general framework of this policy on its territory. It is the Regional Health Agency (ARS) which has a key role in its strategic planning. This regalian administrative establishment works on a better distribution of the care supply and takes actions to abolish inequalities in access to care. The regional health plan, various zoning actions, and many other tools help the 
ARS in these objectives, leaving aside Orléans Métropole. In that respect, the latter develops other means of action.

Concomitantly, the metropolis is in competition with other administrative levels, including the region. The Centre-Val de Loire Regional Council has responded vigorously to the medical demography of its territory. The local authority has a legal basis on which to base its intervention, linked to specific territorial features. Among its actions, we identify the setting of a "health emergency plan" which materializes, for example, by the financing of multidisciplinary health center projects, or by the dramatic announcement of the hiring of 150 salaried medical doctors within the framework of the "Pro Health General Interest Group". These actions allow the Region to connect directly with the municipalities and health professionals who benefit from regional support, hence excluding the metropolis once more.

Competition also occurs with the neighbor territories of Orléans Métropole. The population from these large territories, spread into around one hundred municipalities, is often compelled to go to the metropolis for medical care. Under these conditions, one could imagine a key role for the metropolis, in trying to regulate care supply at the scale of the urban area. However, the situation evolved differently, with the union of all the neighboring territories of Orléans Métropole within a specific local health contract (CLS). This regulatory system which surrounds Orléans Métropole brings together 6 communities of municipalities grouped into two Poles of territorial and rural balance (Figure 1).

Figure 1: health policies and equipments face to inter-municipal structures in the urban area of Orléans

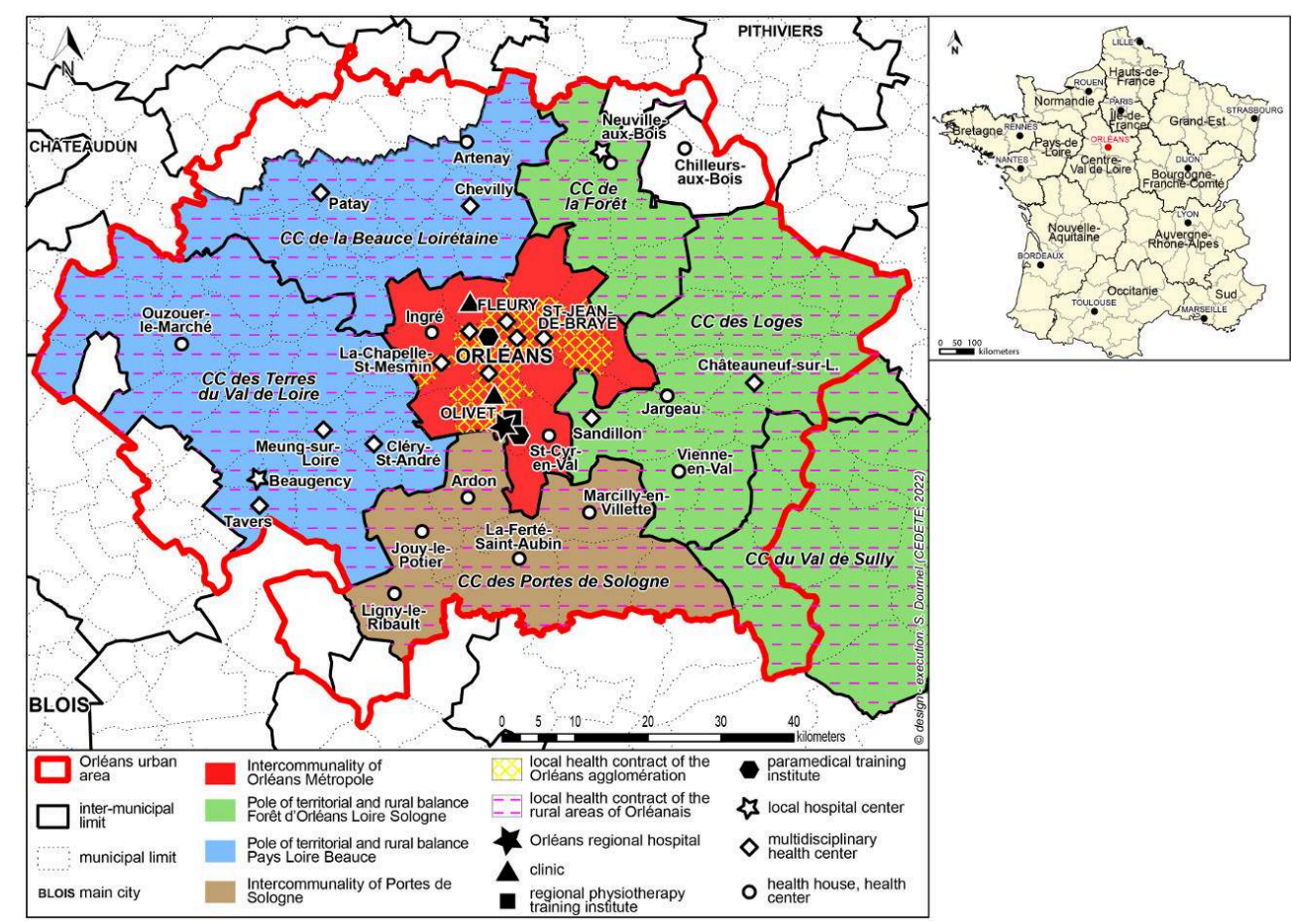

6 Finally, competition occurs also with the municipalities. At first sight, the metropolitan competence is limited, up to now, in order to respect the mayors' capacity for initiative. Thus, while the municipalities keep the possibility to launch an attractive policy with health professionals, the metropolis merely articulates their initiatives, to 
avoid pointless competition. But, the mayors, responding to the grievances of their citizens, increase the number of multidisciplinary health centers and employing doctors, and thus place their actions within the strict municipal framework. Agreements, support and funding are implemented with the ARS and the region, beyond the metropolis.

7 Nevertheless, the metropolis needs to be creative to address the instrumental gaps and build a real capacity for action. For instance, the intercommunality has developed a territorial marketing strategy focused on the issue of healthcare provision, to attract health practitioners. The aim is to make Orléans Métropole known to health practitioners, by presenting the professional and personal opportunities to come and settle in the urban territory, heralded as a source of quality of work and life. This policy refers to prospecting actions in congresses, conferences and medical networks as well as to an important poster campaign in Paris and in cities with university hospitals and medical faculties, located 2 or 3 hours from Orléans. Welcoming days, support for the local installation and networking of health professionals complete the system. In addition, the intercommunality makes land and real estate available to strengthen its general policy of medical attractiveness.

8 Finally, it should be remembered that the coordinating competence is only in its early stages. This will perhaps lead to more developed skills in the area of healthcare in a context of inter-municipal assertiveness.

INDEX

Keywords: metropolization, health, territory, institutional struggle, governance, inter-municipal cooperation

\section{AUTHORS}

PIERRE ALLORANT

Professeur des universités en histoire du droit, POLEN Université d'Orléans

\section{SYLVAIN DOURNEL}

Ingénieur de recherche, docteur en géographie et aménagement, CEDETE, Université d'Orléans

\section{FOUAD EDDAZI}

Maître de conférences en droit public, CRJ Pothier, Université d'Orléans 